\title{
De inrichting van de theologie in de plurale cultuur*
}

\author{
H M Vroom \\ (UP \& VU Amsterdam)
}

\begin{abstract}
Three institutional settings of theology: seminaries, mixed models and free faculties
\end{abstract}

In this contribution three models of the organisation of theology have been described: seminaries, a combination of university and church responsibilities, and free standing theological school and faculties with a contract with a church or with churches. The interests of the various players in the field - churches, universities, governments, students - have been listed, and the models are being evaluated in relation with their potencies to meet the requirements of the emerging secular and religiously plural society.

\section{INLEIDING}

De plurale samenleving vergt dat de theologie anders wordt georganiseerd dan in voorheen christelijke landen gebruikelijk was. In deze bijdrage gaan we op deze vraag in. Eerst geven we een korte typering van de uitdagingen van de plurale cultuur ( $\$ 2$ ). Daarna beschrijven we drie manieren waarop de christelijke theologie is georganiseerd "tussen" universiteit, kerk en overheid ( $\$ 3$ ). Vervolgens beschrijven we de belangen van deze drie partijen $(\S 4)$. Ten slotte gaan we na welke van deze drie manieren geschikt zijn om de theologische bezinning binnen meer religieuze tradities in een land te organiseren $(\S 5)$.

* Hierdie artikel vloei voort uit 'n navorsingsprojek oor die aard en institusionalisering van die teologie waarin die skrywer saam met professor $C \mathrm{~J}$ Wethmar van die departement Dogmatiek en Christelike Etiek in die Fakulteit Teologie (Afdeling B) aan die Universiteit van Pretoria betrokke is. Dr H M Vroom is hoogleraar in Godsdienswysbegeerte, Apologetiek en Ensiklopedie van die Godgeleerdheid aan die Vrije Universiteit te Amsterdam. 


\section{DE UITDAGING IN EEN PLURALE, GESECULARISEERDE CULTUUR}

De snelle culturele veranderingen van de afgelopen decennia hebben hun weerslag op de inhoud van de theologische studie en de institutionele vorm ervan.

\subsection{Institutioneel}

De scheiding tussen kerk en staat heeft in landen als Zuid-Afrika, de USA, Frankrijk en Nederland de vraag opgeroepen of de theologische faculteiten wel aan de staatsuniversiteiten gehandhaafd kunnen worden. Voor "religious studies" ziet men geen probleem, voor confessioneel bepaalde theologie wel. (We hebben gezien hoe de scheiding kerk-staat in Nederland aanleiding was tot de invoering van de duplex ordo). De scheiding van instituten voor "religious studies" en theologische seminaries betekent vaak een scheiding tussen geseculariseerde en confessionele instituten.

Voor beide instellingen leidt dit tot problemen. Bij de religious studies departments rijst de vraag welk emplooi er voor de afgestudeerden is. Indien de studenten leraar godsdienst worden in het openbaar onderwijs, dan ontstaat er een generatie niet-confessionele godsdienstleraren. Indien "religious studies" aan openbare universiteiten geseculariseerd is, rijst de vraag of het godsdienstonderwijs niet erg aan de buitenkant blijft en het hart van de religie werkelijk raakt ${ }^{1}$. Indien de religious studies departments niet genoeg studenten trekken, lopen ze gevaar om gesloten te worden.

Maar ook voor de confessionele theologische seminaria ontstaat er een probleem. In een plurale, geseculariseerde samenleving kan confessionele theologie buiten het publieke leven worden geplaatst, zowel door de privatisering van geloof als door kerkelijke groeperingen die zich los van de verdere cltuur wensen te ontwikkelen en die zich aan de confrontatie met andersdenkenden wesen te onttrekken. Christelijke theologie heeft $\mathrm{m}$ i te maken met de kritiek die vanuit het Evangelie op de mens toekomt en met de kritiek van anders-denkenden. Juist het spanningsveld tussen deze beide is immers de vruchtbaarste grond voor de christelijke theologie. Vanuit het Evangelie rijst de vraag naar het christelijk gehalte van de kerk. Men denke hierbij aan Barth's omschrijving van de theologie (die hij feitelijk onder de definitie van dogmatiek geeft):

"Dogmatik ist als theologische Disziplin die wissenschaftliche Selbstprüfung der christlichen Kirche hinsichtlich des Inhalts der ihr eigentümlichen Rede von Gott"2. 
Men kan ook meegaan met de omschrijving van Charles Wood:

"Christian theology may be defined as critical inquiry into the validity of Christian witness" 3 .

Vanuit het Evangelie valt ook een bepaald licht op de cultuur. Omdat de cultuur vanuit het Evangelie onder kritiek wordt gesteld, heeft de theologie een bijdrage te leveren aan de cultuur als geheel. Daarom zal de christelijke theologie de dialoog met andere stromingen moeten zoeken. Omgekeerd kan de theologie de kritische vragen vanuit andere levensbeschouwelijke tradities en vanuit de geseculariseerde wetenschap niet ontlopen. Juist deze kritische vragen dwingen de theologie tot kritische reflectie en kritisch onderzoek. Daarom behoort de theologie in de academische wereld thuis daargelaten hoe men de relatie ermee organiseert. In het spanningsveld van loyaliteit aan het Evangelie en aan de kerk, kritiek vanuit de kritische wetenschap, geseculariseerd denken en vanuit andere religieuze tradities, wordt de theologie gedwongen zich rekenschap te geven van echte boodschap van de bijbel, de christelijke geloofswaarheid en de taak van christenen in deze wereld. We kunnen dit veld in de volgende termen vatten: kerk, universiteit, secularisatie, pluralisme. De hoofdvraag in deze bijdrage is welke institutionele vormgeving de theologie het beste in het midden van dit spanningsveld brengt. Ligt de theologische faculteit heel dicht bij de kerk, dan kan de loyaliteit met de kerk groot zijn, maar kan de theologie het zich licht te gemakkelijk maken wat betreft kritiek en creativiteit. Is de theologie in de eerste plaats deel van de academische wereld, dan kan de uitdaging om het Evangelie als kritische en bevrijdende boodschap aan de geseculariseerde wereld verwateren. Begeeft de theologie zich primair in het veld van de godsdienstwetenschappen, dan kan de loyaliteit met de eigen confessionele traditie daaronder lijden. Elke oplossing heeft voor en tegen. De vraagstelling is welke institutionele omgeving optimaal is voor de christelijke theologie.

\section{2 "Ministerial formation"}

De institutionele afwegingen lopen parallel met de vraag op welke wijze predikanten het beste kunnen worden opgeleid. In de Wereldraad van Kerken spreekt men in verband daarmee van "ministerial formation" 4 . Ook in de training van predikanten gaat het immers om geloofsengagement en spiritualiteit, kritisch denken, het ondergaan van godsdienstkritiek en kritiek vanuit andere religieuze tradities en het vermogen de Schrift te verstaan als het Woord van God tot mensen in de context waarin zij leven. 
De vorming van aanstaande predikanten vindt plaats in het spanningsveld van kerk, kritisch denken, secularisatie en pluralisme. Omdat de cultuur verandert, kan het nodig zijn om meer aandacht te schenken aan de vorming van de studenten dan vroeger. In de "christelijke cultuur" vond er ook buiten kerk, school en gezin geloofsoverdracht plaats. Maar sedert de "christelijke cultuur" is verschrompeld en veel studenten minder dan vroeger bij de kerk zijn betrokken, wordt het belangrijker om uitdrukkelijk aandacht te geven aan de persoonlijke vorming van de student als christen en aanstaande voorganger. $\mathrm{Bij}$ deze vorming gaat het niet om een training in praktische vaardigheden, maar om de manier waarop de theologische studenten in het spanningsveld van de huidige cultuur staan, hoe zij de kritische vragen en de geloofsaanvechtingen leren verwerken, hoe zij tot eigen, creatieve inzichten en standpuntbepalingen komt en hoe zij met anderen omgaan. De omgang met de Schriften en een levend geloof zijn de voornaamste inspiratiebronnen voor de predikanten willen zij later hun taak in de missio Dei kunnen vervullen.

Het staat niet vast dat geseculariseerde universiteiten ruimte zullen bieden voor deze aspekten van de theologische studie en vorming. Velen zullen een tegenstelling zien tussen wetenschappelijk denken en religieuze vorming. Maar als men het object van de theologie omschrijft als de openbaring van God of het Woord van God, dan valt het moeilijk om de studie van de theologie strikt te scheiden van het geloof dat naar dit Woord hoort en zich door dit Woord laat leiden. Terwijl de theologische vakgebieden in diverse specialismen uiteenwaaieren, ligt het integrerend centrum van de theologie in de kennis van Gods Woord5. Dit inzicht heeft implicaties voor de docenten en voor de studenten. Het theologische van hun onderscheiden vakgebieden ligt in de betrokkenheid van elk afzonderlijk vakgebied op de kennis van Gods openbaring. Oud-joodse teksten kunnen, bijvoorbeeld, het object van godsdienstwetenschappelijk onderzoek zijn, maar in de bijbelwetenschap gaat het om de kennis van de geschriften van het Oude en Nieuwe Testament. De specialisatie van de bijbelwetenschap ligt in de uitleg van de teksten in de historische en literaire context, maar het doel blijft om een bijdrage te leveren aan het begrijpen van wat de teksten (willen) zeggen over God, mens en wereld. Dit theologisch aspect van de studie vergt engagement van docent en student beide. De docent draagt niet alleen kennis over maar ook een manier van omgang met de teksten, het verleden van de kerk en de kritiek van ongelovigen en anders-gelovigen. Zo kan ook voor de student de studie plaatsvinden in het spanningsveld van kerk en wereld. 
De theologie heeft zowel met de kerk te maken als met de academische wereld en de overheid. De relatie tussen kerk en overheid is per land verschillend geregeld. De regeling hangt van twee factoren af, ten eerste van de manier waarop de scheiding tussen kerk en staat en de gelijkberechtiging van diverse groepen is geregeld, en ten tweede de rijksbijdrage aan de academische studie. In sommige landen onderhoudt de overheid officieel geen banden met kerkelijke en andere religieuze groeperingen, maar in andere landen onderhoudt ze onpartijdig gelijke banden met de diverse groeperingen. In landen waar de overheid bijdraagt aan de bekostiging van de universiteiten of de opleidingsinstituten voor geestelijke ambten of aan de studiekosten van studenten, hebben de kerk en de theologie direct of indirect ook met de overheid van doen. Omdat deze praktische regelingen rondom de kerk-staat-verhouding en de bekostiging van het hoger onderwijs per land sterk uiteenlopen, zijn er allerlei uiteenlopende regelingen inzake de relaties van de theologie met kerk en universiteit. We kunnen drie modellen onderscheiden: 1) met primair kerkelijke verantwoordelijkheid, 2) met gedeeltelijk kerkelijke en gedeeltelijk universitaire verantwoordelijkheid, en 3) met primair universitaire verantwoordelijkheid. We gaan de drie modellen eerst na, en geven er enkele voorbeelden van, om vervolgens de belangen van de drie "partijen" te schetsen.

\subsection{Kerkelijk seminaria}

\section{a) Seminaria voor rekening van de kerk}

Er bestaan wereldwijd vele seminaria, die door kerken worden bestuurd en bekostigd. Onderdelen van het bestuur worden dan meestal aan een curatorium uitbesteed, terwijl de bisschop of de synode zich vaak rechten voorbehoudt, met name inzake het globale studieprogramma en de regelingen van toelating van studenten en benoemingen van hoogleraren, docenten en leden van het curatorium. In Nederland volgen de Gereformeerde Kerken (zg. Kampen II: "vrijgemaakt") dit model6. De Eglise Réformée dé France heeft op deze wijze een theologisch instituut met afdelingen te Parijs en te Montpellier.

\section{b) Seminaria met rijkssubsidie}

In Nederland bestaan er kerkelijke seminaria die in het universitaire bestel zijn opgenomen, die door en vanwege de kerken worden bestuurd en door 
de overheid worden gesubsidieerd: de Theologische Universiteit der Gereformeerde Kerken te Kampen en de Katholieke Theologische Universiteiten te Utrecht en te Tilburg7. Deze theologische universiteiten zijn door de overheid als zogenoemde "aangewezen instellingen" erkend; zij dienen net als alle universitaire instellingen te voldoen aan eisen van kwaliteit en doelmatigheid.

\subsection{Duplex-ordo-modellen}

\section{a) Het aanleun-model}

Kerken die voor hun seminarie geen overheidssubsidie ontvangen, vestigen hun seminarie soms bij een brede universiteit met een afdeling theologie en/of godsdienstwetenschap. Zo wordt in een rapport van de Anglicaanse Kerk opgemerkt dat de "Theological colleges" personeelskosten uitsparen door van universitair onderwijs gebruik te maken en samenwerking met andere kerken te zoeken ${ }^{8}$. Ook de seminaries van de United Reformed Church zijn in universiteitssteden gevestigd. In dit model heeft de kerk geen bevoegdheden ten aanzien van de universitaire faculteit. De omvang van de theologische staf van het seminarie is doorgaans zeer bescheiden.

In Nederland heeft een hervormd/gereformeerde commissie in 1989/90 aan een plan gewerkt om voor de Samen-op-weg-kerk een "aangewezen instelling" aan te vragen, die vervolgens bij de universiteiten onderwijs zou inkopen. Omdat deze instelling door de overheid zou worden bekostigd, zou dit een krachtige instelling kunnen zijn met een goede onderhandelingspositie ten aanzien van de universiteiten. Dit plan is niet doorgegaan?.

\section{b) Het aanvullings-model}

In het aanvullingsmodel volgen studenten de academische studie en vult de kerk op onderdelen aan. Dit model is gevolgd in de Nederlandse duplex ordo, waarin de kerkelijke opleidingen door de overheid als aangewezen instellingen zijn erkend en ook worden gesubsidieerd. $\mathrm{Zij}$ moeten aan overheidsnormen van kwaliteit en doelmatigheid voldoen. De overheid subsidieert niet alleen onderwijs maar ook onderzoek in de kerkelijke vakken.

Dit aanvullingsmodel komt ook in andere landen voor, maar dan (veelal) niet gesubsidieerd. Bij het aanvullingsmodel kan een kerk een verband met een faculteit aangaan en zekere rechten verkrijgen, zoals deelname aan benoemingscommissies van docenten of veto-recht bij benoemingen.

In Duitsland kent men theologische faculteiten aan brede universiteiten. Uit godsdienstvrijheid leide men niet af dat een staatsuniversiteit 
"neutraal" zou moeten zijn, maar dat de levensbeschouwelijke stromingen wat theologische onderwijs en onderzoek betreft gelijkberechtigd behoren te worden - het omgekeerde van de Nederlandse regeling van 1876 dus. Men kent dus geen duplex ordo. De Duitse universiteiten hebben veelal een protestantse en een katholieke faculteit. Deze regelingen vallen onder de jurisdictie van de Duitse deelstaten. Zo heeft de Evangelische Landeskirche in Nieder-sachsen bijvoorbeeld een verdrag met het Land Niedersachsen van 19 maart 1955 waarin het Land zich onder andere verplicht tot het onderhouden van een protestantse theologische faculteit aan de universiteit Göttingen. De kerk heeft veto-recht op benoemingen. Omgekeerd heeft de kerk zich er onder andere toe verplicht dat aanstaande predikanten minstens drie jaar theologie hebben gestudeerd in een "deutschen staatlichen Hochschule" 10 . Bovendien heeft de landsregering regelmatig overleg met de kerk. $\mathrm{Na}$ deze universitaire studie dienen de aanstaande predikanten gedurende meer dan een jaar nog een kerkelijke aanvullende opleiding aan een kerkelijk seminarie te volgen.

Iets anders ligt het in Schotland en Ierland. De Schotse en Ierse Hervormde Kerken vullen de academische theologische studie aan met vakken en stages. De Schotse Hervormde Kerk overweegt een systeem waarbij studenten gedurende de gehele universitaire studie extra "kerkelijke" vakken bestuderen, met vormende en rechtstreeks kerkelijke elementen. De kerk kan deze studieonderdelen uitbesteden aan, bijvoorbeeld, de praktisch theoloog van de universitaire faculteit. Dan "koopt" de kerk de aanvulling in.

\subsection{Het model van vrije faculteiten}

Een vrije universitaire faculteit van christelijke theologie of een zelfstandige Theologische School kan een complete theologische studie inclusief predikantsopleiding bieden, en zo op eenzelfde wijze werken als een kerkelijk seminarie. De universiteit heeft dan vaak (maar niet altijd) een contract met een kerk waarin de hoofdlijnen van het studieprogramma, de benoemingsprocedures van docenten en kerkelijke inspraak zijn geregeld. De minimale overeenkomst die er tussen een theologische school en een kerk moet bestaan, is de verklaring van de kerk dat studenten die hun studie aan de school hebben voltooid, toegelaten worden tot de kerkelijke toetsing voor het ambt. In dit model is de kerk niet rechtstreeks verantwoordelijk voor het studieprogramma maar heeft zij door de overeenkomst feitelijk grote invloed op de gang van zaken. Dit model wordt in Nederland gevolgd bij de twee bijzondere universiteiten, de Katholieke Universiteit Nijmegen en de Vrije Universiteit te Amsterdam. De Wet op het Hoger 
Onderwijs en Wetenschappelijk Onderzoek (1992) bepaalt dat deze bijzondere universiteiten door de overheid worden bekostigd.

Dit model van zelfstandige theologische faculteiten die contracten hebben afgesloten met een of meer kerkgenootschappen, komt vaak voor in de U S A; het komt ook voor in Azië en Afrika, vaak bij "interdenominational schools". In de U S A wordt de academische kwaliteitscontrole uitgeoefend door de Association of Theological Schools. Bekostiging vindt plaats uit (hoge) collegegelden, giften van particulieren en daaruit ontstaan vermogen.

Bij sommige Theological Schools draagt de kerk zelf een deel van de kosten bij en heeft de kerk ook een aantal zetels in het bestuur. In veel gevallen hebben deze "Theological Schools" zich uit kerkelijke seminaries ontwikkeld. Zo is New Brunswick Theological Seminary, een van de twee theologische seminaries van de Noord-Amerikaanse Hervormde Kerk (RCA), sterk "interdenominational" geworden. Kerkgenootschappen erkennen dan een ruim aantal theologische opleidingen en hebben hun eigen kerkelijk examen om de motieven en eventueel de kennis van afgestudeerden te toetsen alsvorens zij predikant in hun kerk kunnen worden. Steeds meer "Theological Schools" hebben studenten van allerlei denominaties; hun ligging of profiel is vaak belangrijker voor de keuze door de student dan hun denominationele herkomst. Vaak, maar lang niet altijd, zijn zulke Theological Schools zelfstandige instellingen, soms bij een brede universiteit gevestigd maar daarmee niet verbonden. De grootste "reformed" School in de USA is Fuller Theological Seminary te Pasadena. Fuller heeft een uitvoerige "Statement of Faith" (die elk jaar door de docenten wordt onderschreven), is geheel "vrij" en zelfstandig, en rekent enerzijds met de behoeften en wensen van kerkgenootschappen en anderzijds met de eisen van de Association of Theological Schools ${ }^{11}$.

\section{BELANGEN VAN UNIVERSITEIT, OVERHEID, STUDEN- TEN EN KERK}

Aldus kan men drie modellen van de organisatie van de theologie in het spanningsveld van kerk-universiteit-overheid onderscheiden. Dan gaan we nu de verantwoordelijkheden en belangen van de drie partijen na.

1) De overheid heeft belang bij kwalitatief goed hoger en wetenschappelijk onderwijs en onderzoek; daarom bekostigt de overheid in veel landen een deel van het wetenschappelijk onderwijs en onderzoek en neemt ze maatregelen om de kwaliteit ervan te waarborgen. $\mathrm{Bij}$ het onderzoek en onderwijs behoort ook de theologie. Veel wetenschappelijke opleidingen 
hebben maatschappelijke belangen. Dat geldt ook van de theologie. De overheid is er namelijk mede verantwoordelijk voor kaders te scheppen voor de overdracht van waarden, idealen en normen en zodoende voor levensbeschouwelijke tradities. In dat verband bekostigt de overheid in een aantal landen de ambtsopleidingen van tradities. De beide verschijnselen van pluralisme en secularisatie vergen een zorgvuldiger overheidsbeleid dan men zich in een uniforme cultuur kon veroorloven. Om de kwaliteit van de opleidingen tot predikant, pastoor, imam en geestelijke in het algemeen te waarborgen, kan de overheid ze opnemen in het systeem van kwaliteitsbewaking voor het academische onderwijs en onderzoek of deze bewaking overlaten aan een Associatie van theologische opleidingen.

2) De universiteit wordt gekenmerkt door een zoeken naar inzicht en waarheid over de gehele werkelijkheid. Godsdienstwetenschap, theologie en wijsbegeerte vallen binnen dit kader. De universiteit heeft zowel belang bij een goede wetenschappelijke standaard van onderwijs en onderzoek als bij voldoende instroom van studenten. In sommige landen meent men dat rijksuniversiteiten geen theologische faculteiten kunnen hebben, omdat de theologische studie door de opleiding tot predikant of pastoor steeds een confessionele positiebepaling zal kennen. Zo kennen de staatsuniversiteiten in de U S A en Frankrijk (zoals vermeld) geen theologische faculteiten; de Duitse deelstaten en de Elzas hebben de "neutraliteit" van de overheid opgelost door zowel rooms-katholieke als protestantse faculteiten te vestigen. Aan de private universiteiten in Noord-Amerika is wel ruimte voor theologische faculteiten.

Sedert men in de wijsbegeerte de gedachte van neutrale wijsbegeerte heeft laten vallen, zal ook de overheid de idee van neutraliteit moeten laten vallen - anders kiest zij partij voor die liberale levensbeschouwing, die elke levensbeschouwelijke keuze tot Privatsache verklaart (hetgeen lang niet alle liberalen doen). Daardoor wordt de indruk gewekt als zou het publieke domein neutraal zijn'12. Vanwege het belang van levensbeschouwing voor de cohesie in de samenleving en de menselijke zinbeleving zal de overheid studie op het gebied van godsdienstwetenschap, wijsbegeerte en theologie eerder moeten bevorderen dan afremmen. De neutraliteit van de overheid neemt dan de vorm aan van gelijkberechtiging van religieuze groeperingen. Het is belangrijk dat de kritische, geëngageerde beoefening van de theologie ook aan de staatsuniversiteiten een plaats heeft. De universiteiten zien uiteraard toe op het academisch niveau van opleiding en onderzoek.

3) De studenten hebben belang bij een theologische studie die hun meer beroepsperspectieven laat dan alleen het predikantschap. Tegelijk hebben veel studenten die predikant willen worden, in onze post-christelijke 
cultuur meer belang bij vorming in de traditie dan vroegere generaties studenten. Predikanten moeten immers kritisch en creatief in kerk en cultuur staan. Daarnaast blijken er in veel landen mensen op iets oudere leeftijd behoefte te hebben aan een studie op theologisch en levensbeschouwelijk gebied. De culturele situatie zoals die onder invloed van individualisering, globalisering, vereconomisering en pluralisme is ontstaan, maakt deze wens begrijpelijk. Zowel vanuit de kerken als vanuit de overheid gezien, is het belangrijk om aan deze behoefte tegemoet te komen.

4) De kerk heeft belang bij een predikantsopleiding die studenten zowel met de christelijke traditie vertrouwd maakt als met de cultuur waarin zij het Evangelie mogen uitdragen en mogen bijdragen aan de vorming van andere mensen. De kerk kan de predikantsopleiding geheel of ten dele zelf betalen, haar onderbrengen in het normale universitaire systeem of met overheidssubsidie in eigen hand houden. De financiële situatie van de kerk en de wijze van bekostiging van het hoger onderwijs spelen hierbij een grote rol. Onder verwijzing naar Barth's omschrijving van de theologie moet met nadruk worden gesteld dat de kerk zelf behoefte heeft aan kwalitatief goede, kritische theologie ${ }^{13}$.

Zoals we zien, zijn de elementen waarmee men bij de organisatie van de theologie binnen het universitaire bestel moet rekenen: 1) godsdienstvrijheid en gelijkberechtiging van tradities, 2) eisen van wetenschappelijke kwaliteit, 3) de vrijheid en verantwoordelijkheid van de kerken wat betreft de overdracht van hun traditie, 4) het studentenaantal, 5) de rijksbijdrage in de bekostiging van de universiteiten, 6) de rijkssubsidiëring van de ambtsopleidingen, 7) rijksbijdragen in de studiekosten van studenten.

\section{RELIGIEUS PLURALISME EN DE THEOLOGIE}

De grote vraag is natuurlijk hoe de theologie in een plurale samenleving het beste georganiseerd kan worden. Ik neem theologie nu als geloofsdoordenking van een levensbeschouwelijke traditie: christendom, islam, humanisme enzovoorts. We kunnen vanuit drie perspectieven kijken, vanuit de religieuze tradities, vanuit de universiteit en vanuit de overheid. We volgen hier de geschetste modellen. We volgen dezelfde procedure als in de paragrafen 3 en 4: we kijken eerst hoe het eruit zou zien en kijken daarna vanuit de drie verschillende perspectieven naar de voors en tegens. Soms zal ik kortheidshalve "kerken" schrijven waar ik "religieuze organisaties" bedoel. 


\subsection{De drie modellen}

\subsubsection{Het seminarie-model}

\section{a) Voor eigen rekening}

Elke religieuze traditie kan, indien gewenst, een eigen opleidingsinstituut inrichten. Deze instituten vallen geheel voor de verantwoordelijkheid van de religieuze organisatie, die het programma bepaalt, docenten aanstelt en studenten toelaat. De kosten worden bestreden uit collegegelden, giften en bijdragen vanuit de organisatie zelf.

\section{b) Met overheidssubsidie}

Hetzelfde model is denkbaar met rijksbekostiging danwel subsidie. De overheid is gehouden aan gelijkberechtiging van religieuze organisaties, wat inhoudt dat er naar rato van het studentental wordt bekostigd. Een overheid die subsidie verstrekt, zal kwaliteitseisen stellen. De kwaliteitswaarborgen kunnen op meer manieren worden verkregen, maar redelijk lijken een regeling voor alle theologische instellingen (ongeacht hun confessie) of opname in de regelgeving voor het hoger onderwijs als geheel. De laatste regeling ligt het meest voor de hand, want ze is de meest eenvoudige.

\subsubsection{Duplex-ordo-modellen}

\section{a) Het aanleun-model}

Indien de diverse religieuze organisaties hun seminaria vestigen in steden met een "religious studies department" kunnen zij van universitaire voorzieningen gebruik maken. Samenwerking inzake gebouwen, beheer en bibliotheek kan wellicht tot enige besparing leiden, maar de seminaria zullen toch het merendeel van de kosten daarvan moeten dragen. Interessanter lijkt de "inkoop" van colleges. Men moet zich daarvan echter geen overdreven voorstelling maken, zoals straks zal blijken als we nagaan welke vakken de seminaria bij "religious studies" zouden moeten en willen inkopen. Zoveel overlap zal er niet zijn.

In het geval een hervormd seminarie, zoals te Cambridge ( $U K K$ ), aanleunt tegen een theologische faculteit (en de studenten drie jaar zonder betaling van collegegeld mogen studeren), kan het seminarie gebruik maken van de godsdienstwetenschappen, de bijbelwetenschap, de kerkgeschiedenis en eventueel van delen van de systematische en praktische theologie. Zodra de "inkoop" geld kost, moet de kerk overwegen of ze de vakken zelf wil geven danwel "inkopen".

Vaak zijn seminaries gevestigd bij "religious studies departments" van universiteiten. Denkbaar is een ring van theologische seminaries rond 
een "religious studies department". De vraag is echter of men veel vakken wil uitbesteden. Zal een moslimse opleiding bijvoorbeeld Koran-exegese door een ongelovige willen laten geven? Als men veel samendoet en op onderdelen aanvult, ontstaat het aanvullingsmodel.

\section{b) Het aanvullingsmodel}

Het aanvullingsmodel zou inhouden dat islamitische, joodse en christelijke studenten een gezamenlijk programma in religious studies volgen en elk hun eigen speciale vakken extra verkrijgen op een seminarie van hun traditie. Men denke aan het oecumenisch Fuller Theological Seminarie dat afzonderlijke aanvulling levert aan presbyteriaanse, baptistische, hervormde enzovoorts studenten. Is een dergelijk model toepasbaar wat betreft moslims, christenen, hindoes en anderen?

Met oog op de praktijk is het goed om zich af te vragen welke studieonderdelen zulke studenten gezamenlijk kunnen volgen. Islamitische studenten studeren Arabisch, Joodse ongevocaliseerd Hebreeuws, christelijke Grieks en Hebreeuws, hindoe studenten Sanskriet, enzovoorts. Laat ik wat betreft de vraag naar overlapping van studieprogramma's, die studenten van diverse studies gezamenlijk kunnen volgen, een voorbeeld mogen geven. Aan de Vrije Universiteit bestaat een opleiding godgeleerdheid en een opleiding religious studies. De verplichte delen van deze twee studies overlappen voor minder dan vijf maanden studie; wat de opleiding godgeleerdheid betreft is dat ongeveer tien procent van de studielast; in hoofdzaak wijsbegeerte, ethiek, sociale wetenschappen en godsdienstfenomenologie. Het staat niet eens vast dat elke islamitische opleiding al deze vakken verplicht zal stellen. Toch zou waardevol kunnen zijn om studenten godsdienstwetenschap en theologie voor een periode van bijvoorbeeld een jaar gezamenlijk vakken te laten bestudenren.

Een belangrijke factor is echter de financiering. Een arme kerk met een klein seminarie zal wel gedwongen zijn om zoveel mogelijk vakken van de universitaire studie theologie of religious studies te "gebruiken", terwijl een rijkere kerk de financiële vrijheid vermoedelijk zal gebruiken om de aanvullingen te geven die men wenselijk acht en de vakken die men belangrijk vindt in eigen beheer te doen onderwijzen. Soms bestaat er een groot verschil tussen wat men ideaal acht en wat men kan verwezenlijken.

\subsubsection{Vrije faculteiten met een contract met een religieuze organisatie}

De derde mogelijkheid bestaat in contracten tussen religieuze organisaties en universiteiten waarbij de "kerken" randvoorwaarden stellen wat betreft het studieprogramma en de selectie van de wetenschappelijke staf. Op die 
manier kan een universiteit een protestantse, een rooms-katholieke en een islamitische faculteit herbergen. In goed overleg kan besloten worden om sommige colleges - zoals godsdienstwetenschappen en westerse wijsbegeerte - te combineren. Docenten uit de ene opleiding kunnen in de andere opleiding colleges verzorgen over hun eigen religie. Zaken als de bibliotheek, de gebouwen en het personeelsbeheer kunnen gezamenlijk worden gedaan. Wat de kwaliteitseisen betreft, zou een dergelijk samenstel van faculteiten binnen de normale universitaire regelgeving vallen.

\subsection{De belangen van universiteit, overheid en religieuze gemeen- schappen}

Voor de afweging welk model het meest wenselijk is, moeten we de belangen van religieuze organisaties, universiteit en overheid nagaan. Een belangrijke maar onzekere factor is de wijze van bekostiging van het hoger onderwijs, die internationaal sterk varieert.

\subsubsection{De overheid}

In een plurale samenleving heeft de overheid belang bij het bevorderen van onderling begrip tussen religieuze tradities, bij consensus-vorming over morele kwesties en bij het bevorderen van leefverbanden waarin burgers solidair zijn met elkaar. Bovendien heeft de samenleving als geheel belang bij verantwoorde religie. Ik kan daarop in dit verband niet uitvoerig meer ingaan (zie hoofdstuk 4). Kort gezegd, de samenleving heeft behoefte aan een culturele en morele consensus in de bevolking; zonder een dergelijk maatschappelijk draagvlak dreigen zinverlies en spanningen tussen bevolkingsgroepen, uitlopend op eenzaamheid, onverschilligheid en soms gewelddadigheid. Voor de kwaliteit van de samenleving zijn zingevende tradities van levensbelang. Levensbeschouwelijke tradities spelen een grote rol in de vorming van beelden van het goede leven. Uitwisseling tussen mensen uit diverse levensbeschouwelijke tradities is dus een voorwaarde voor een goed maatschappelijk draagvlak in de samenleving. De overheid moet en mag dus proberen te voorkomen dat er teveel sekten ontstaan die zich aan de samenleving als geheel onttrekken. Eén van de meest voor de hand liggende en minst onsympathieke maatregelen om dat te bereiken is dat de overheid de opleiding van voorgangers subsidieert en een publiek debat over godsdienst en moraal stimuleert. Daarbij is de overheid gehouden om binnen de kaders van de verdere wetgeving godsdienstvrijheid te garanderen en diverse groepen gelijk te behandelen. Mijns inziens is dit een overheidstaak: stimuleren van samenwerking en dialoog. Daarnaast heeft de overheid in het algemeen belang bij goed wetenschappelijk onder- 
wijs en, indien zij hoger onderwijs financiert, bij een efficiënte aanwending van algemene middelen.

\subsubsection{Religieuze groeperingen}

De religieuze groeperingen hebben belang bij voldoende aantal voorgangers met een goede opleiding, die de taken die zij moeten verrichten naar behoren kunnen vervullen. Zij kunnen de opleiding in eigen beheer regelen of ook aansluiten bij subsidiering vanwege de overheid. In landen waar studenten het hoger onderwijs grotendeels betalen, zijn de kerken ten dele afhankelijk van de keuzen die studenten zelf maken. Van hieruit kan men begrijpen dat veel theologische seminaries in de USA gedurende de laatste twintig jaar oecumenisch zijn geworden: de studenten kozen zelf hun seminarie en meldden zich vervolgens bij de kerk die zich in veel gevallen naar de keuzen van de studenten richtte. Voor hun ambtsopleidingen zijn de kerken afhankelijk van de aanmelding van studenten en de financiering van het hoger onderwijs.

Religieuze groeperingen hebben over het algemeen belang bij godsdienstvrijheid. Voor de christelijke kerken is het zowel nationaal als internationaal van belang dat zij hun activiteiten in vrijheid kunnen ontplooien. Dit vergt dat de kerken enerzijds godsdienstvrijheid in eigen land bevorderen en er anderzijds voor zorgen dat ze door de privatisering van geloof niet zozeer marginaliseren, dat het zout zijn kracht verliest. Tot de taken van de kerk behoort - en dat niet alleen naar reformatorische opvatting - het opkomen voor de zwakken in de samenleving en het protest tegen allerlei vormen van onrecht zoals de achterstelling van mensen vanwege geslacht, milieu, ras en nationaliteit. Omdat Gods Woord betekenis heeft voor de gehele cultuur mag de kerk zich niet in een eigen terrein opsluiten of laten opsluiten. Daarom moet de kerk godsdienstvrijheid en pluraliteit aanvaarden en proberen er publieke vormen voor te vinden. De theologie speelt hierin een grote rol, niet alleen in de reflectie maar ook in de "ministerial formation". We kunnen dit belang van de "kerken" benoemen met de termen godsdienstvrijheid en dialoog.

\subsubsection{De universiteit}

Een omschrijving van de belangen van de universiteit wat betreft de beoefening van godsdienstwetenschappen en theologie zou een veel bredere beschouwing over de universiteit als geheel vergen. Factoren die een rol spelen zijn vorming (Bildung), voorbereiding op maatschappelijke functies, opleiding tot zelfstandige behandeling van vraagstukken, kennis van de werkelijkheid en dialoog over de waarheid over God, mens en wereld. 
Zonder dat hier verder te beargumenteren ga ik ervan uit dat de vraag naar "de mens", "de wereld" en dus ook de vraag naar "het transcendente" tot het onderwerp van onderzoek van de universiteit als geheel behoort. Religieuze en levensbeschouwelijke vragen behoren aan de universiteit te worden doordacht. Niet alleen de vormen van godsdienstigheid zijn het object van onderzoek, maar juist ook de waarheidsclaims inzake het transcendente en de betekenis ervan voor de overige werkelijkheid.

De universiteit heeft belang bij studenten omdat zij kennis wil overdragen en mensen wil vormen. Voorzover universiteiten voor hun financiën van studenten afhankelijk zijn, hebben zij belang bij grotere studententallen.

Wat de beoefening van de "theologie" betreft heeft de universiteit belang bij de kwaliteit van onderwijs en onderzoek. Daartoe is een wetenschappelijke staf van voldoende omvang nodig die voldoende tijd heeft om zelfstandige studie te verrichten. Voor de westerse cultuur is een nieuwe vraag hoe de universiteiten zich opstellen inzake het religieus pluralisme anders dan door afstandelijk godsdienstwetenschap te beofenen.

\subsection{Religieus pluralisme en theologie}

Welk van de drie modellen van theologie in de plurale samenleving verdient de voorkeur? Ik vind de volgende twee principes doorslaggevend:

a) Theologie moet zich (krachtens academische vrijheid en godsdienstvrijheid) in vrijheid naar haar eigen aard kunnen ontwikkelen.

b) Binnen de plurale samenleving en de academie behoort geloofsverantwoording en onderlinge dialoog tot de primaire opgaven van de theologie of filosofie van de diverse religieuze gemeenschappen.

De vraag is dan hoe zich de drie beschreven modellen tot deze beide principes verhouden. Het seminarie-model waarborgt de vrijheid van de theologie; de dialoog kan georganiseerd worden door een samenwerkingsverband van seminaries van verschillende religieuze tradities. Het duplexordo-model biedt weliswaar garanties voor onderlinge dialoog, maar doet $\mathrm{m}$ i tekort aan de vrijheid van de theologie om zich werkelijk integraal als christelijke, islamitische etcetera theologie te ontwikkelen. Een doorslaggevend praktisch bezwaar, dat hiermee samenhangt, is, zoals gezegd, dat het gemeenschappelijk gedeelte van de diverse theologische studies gering is. Moslims zullen niet toestemmen in geseculariseerd onderzoek van de Koran, enzovoorts. Een grondbeginsel van de plurale samenleving behoort te zijn dat de geseculariseerde levensbeschouwing niet tot basis en norm 
wordt verheven. Het model van vrije faculteiten doet recht aan de vrijheid van de theologie, maar kan tot isolationisme leiden. Net als bij het seminarie-model moet de dialoog worden georganiseerd. Universiteiten kunnen faculteiten voor islamitische, rooms-katholieke, protestantse etcetera theologie inrichten en nagaan welke delen van organisatie en onderwijs gecombineerd kunnen worden. Een christelijke of een islamitische universiteit zou in haar gebouwen een plaats kunnen inruimen voor een islamitisch of christelijk seminarie. Voor de opbouw van de bibliotheek en de uitwisseling van studenten en docenten heeft dit belangrijke voordelen.

Over het algemeen is het wenselijk dat het onderwijs in een andere religie door een vertegenwoordiger van die religie wordt gegeven. Hiermee wordt zowel een kerkelijk als een cultureel doel gediend. De kerk heeft er belang bij dat predikanten zich oefenen in de dialogische omgang met andersdenkenden en de samenleving, dat mensen van verschillende overtuiging begrip voor elkaar opbrengen en samen over samenlevingsvragen spreken.

Mijn voorkeur gaat uit naar het laatste model: een brede universiteit die (in elk geval wat de theologie en filosofie betreft) op een open manier in een bepaalde traditie staat en ruimte biedt aan een seminarie van andersdenkenden. Ik denk dat zo de loyaliteit van een Faculteit aan een bepaalde traditie tot uitdrukking wordt gebracht, terwijl de academische standaard door het universitaire kader wordt gewaarborgd. Mijn tweede keus is de vrije theologische school, mits deze in een interreligieuze associatie van seminaria de dialoog zoekt. Maar ook een theologisch seminarie dat, hoewel zelfstandig, in een universiteit is ingebouwd en dat van de kerk een grote mate van vrijheid krijgt, zoals bijvoorbeeld Princeton Theological Seminary, kan een goed klimaat voor de theologie bieden.

Wat de relatie tussen godsdienstwetenschap en theologie aangaat, valt een gemeenschappelijk jaar aan het begin van de studie te overwegen, waarin een oriëntatie in diverse religies en levensbeschouwingen wordt geboden naast vakken als godsdienstsociologie en -psychologie.

\subsection{Evaluatie van andere voorstellen}

Tot slot wil ik zeer in het kort twee andere voorstellen voor "theologie in plurale cultuur" bespreken, te weten van Kuitert en van De Knijff.

Kuitert meent dat de godsdienstwetenschap niet alleen beschrijvend kan blijven, maar dat zij de godsdienstige waarheidsaanspraken serieus moet nemen ${ }^{14}$. De godsdienstwetenschap kan dit onderzoek alleen laten vallen als ze uitgaat van "een principiële, niet op wetenschappelijk onder- 
zoek berustende voorbeslissing dat we niets kunnen weten over God"15. Kuitert bespreekt vervolgens een methode voor de toetsing van religieuze waarheidsaanspraken en de inrichting van een faculteit der Godgeleerdheid. Zijn voorkeur gaat uit naar een multi-religieuze faculteit met een gezamenlijke onderbouw van godsdienstwetenschap en godsdienstfilosofie $^{16}$. Hij voegt daaraan een vak "natuurlijke theologie" toe. In dat vak moet het discours plaatsvinden over de diverse godsbeelden en beelden van transcendentie. De beroepsopleidingen voor de diverse religies komen dan bovenop deze onderbouw.

De Knijff bepleit:

“een niet-neutrale, van staats- en kerkbemoeienis zo vergaand mogelijk vrije faculteit van godsdienstwetenschap, waarbinnen alle "richtingen", ook de humanistische, de islamitische en joodse studies en opleidingen hun plaats kunnen hebben... (E)en bredere faculteit, waarin ook de filosofie haar plaats heeft"17.

Hij vat de bedoeling van de Nederlandse wetgever in 1876 zo op dat het niet om een neutrale faculteit ging maar om een scheiding van kerk en staat waarbij de vraag naar godsdienstige waarheid niet werd geëlimineerd ${ }^{18}$. Indien men de godsdienstwetenschap zo opvat dat ook de vraag naar God wordt gesteld, komt het aangegeven plurale stelsel in zicht.

Deze voorstellen komen in sterke mate met mijn visie overeen. Mijn visie verschilt in drie opzichten van die van Kuitert. Ten eerste zie ik de natuurlijke theologie niet als een apart, min of meer neutraal vak. De dialoog moet $\mathrm{m}$ i op meer niveaus worden georganiseerd. In de bijbelwetenschap, koranexegese en islamologie kan men spreken over de interpretatie van de bijbel en de Koran. In de systematische christelijke theologie kan men met de moslimse theologen en filosofen spreken. Binnen de godsdienstwijsbegeerte kan men zich zo algemeen mogelijk opstellen (men kan dat vergelijkende theologie noemen) maar ook vanuit de eigen traditie spreken ${ }^{19}$. Ten tweede zie ik, zoals ik al schreef, praktisch weinig ruimte voor een uitvoerige gezamenlijke studie als onderbouw, al zou een gezamenlijk studiejaar te overwegen zijn. Ten derde lijkt het mij binnen de plurale samenleving belangrijk dat de diverse opleidingen een duidelijke band met "hun" religieuze gemeenschap onderhouden en dat de integriteit van een faculteit als christelijke, joodse, humanistische etc. faculteit niet verloren gaat. Een verwaterde, algemene religieuze faculteit is geen goede basis voor werkelijke dialoog. Indien we de bronnen voor inspiratie niet willen laten opdrogen, moet de dialoog gevoerd worden door mensen die 
werkelijk uit deze bronnen putten. Daarmee komt mijn voorstel iets dichter bij dat van De Knijff, mits "vrij van de kerk" niet inhoudt "los van de kerk". Bovendien zijn de beide voorstellen niet op vergelijking van feitelijke programma's gebaseerd en is - opnieuw - de overlap tussen de verschillende studies minder groot dan men denkt.

Omdat levensbeschouwelijke visies op tal van wetenschapsgebieden van invloed zijn, ben ik bovendien voorstander van een christelijke universiteit, zo goed als ik het bestaan van islamitische universiteiten kan begrijpen. Aan zulke universiteiten zou men voor religieuze minderheden een plek voor een seminarie kunnen inruimen, met gebruik van allerlei universitaire voorzieningen. Denkbaar is ook dat men voor vakken als theoretische pedagogiek en rechtsfilosofie bijzondere leerstoelen voor mensen uit religieuze minderheden instelt. Een dergelijke inrichting van de theologie voldoet aan de twee principes die aan het begin van deze paragraaf zijn geformuleerd en doet, voorzover ik zie, het meeste recht aan de belangen van de universiteit, de studenten, de religieuze gemeenschappen en de overheid.

\section{NOTAS:}

$1 \quad$ Zie D Wiebe, Religion and Truth, Mouton 1981.

2 K Barth, Kirchliche Dogmatik I/1, München 1932, 1. Hierbij vallen de terechte kritische kanttekeningen van $\mathrm{H}$ M Kuitert over de uitdrukking "kirchlich" bij Barth te bedenken, in Kuitert, "Kerk en theologie: onheelbare tweespalt?", in: C / A van Peursen e a, Cultuur als partner van de theologie. Opstellen aangeboden aan Prof dr G E Meuleman, Kampen 1990, 109-124, over Barths typering van de theologie als "kirchlich": welke kerk?

3 C M Wood, Vision and Discernment, Atlanta 1985, 21.

$4 \quad$ Zie het tijdschrift van het Program on Theological Education van de World Council of Churches, dat gericht is op de vorming en training van gemeenteleden, ambtsdragers en dus ook predikanten. Vgl bijv. het overzicht van de predikantsopleidingen in Europa: Theological Education in Europe, Conference Herrnhut, Geneva October 1980, Programme on Theological Education, WCC, 1980.

5 Cf Wood, op cit, 57v.

6 Minister Deetman schrijft: "De Theologische Hogeschool te Kampen (Broederweg) heeft op principiële gronden geen gebruik willen maken van de mogelijkheid een bijdrage van overheidswege te ontvangen ten behoeve van de bekostiging van de desbetreffende ambtsopleiding”, Tweede Kamer 1984-5, 19 011 , nrs 1-3, 6 .

7 Vergelijk ook de theologische school van de Christelijk Gereformeerde Kerken, die gedeeltelijk subsidie aanvaardt.

8 Theological Training. A Way Ahead. A Report to the House of Bishops of the General Synod of the Church of England, London October 1992, 60. Men vindt 
14 colleges op 750-850 studenten teveel en adviseert het aantal tot 11 terug te brengen en nauwer samen te werken. De bruikbaarheid van dit aanleun-model is mede afhankelijk van de hoogte van de collegegelden. In Groot-Brittannië behoeven Britse studenten de eerste jaren van hun studie geen collegegeld te betalen.

10 Het rapport met voorstellen van de Interkerkelijke Werkgroep Onderwijs en Onderzoek Theologie (IWOOT), ingesteld voorjaar 1989 door de moderamina van de hervormde en gereformeerde synodes.

11 Vertrag des Evangelischen Landeskirchen in Niedersachsen mit dem Land Niedersachsen, vom 19. März 1955 (Loccumer Vertrag) met de bijbehorende "Zusatzvereinbarung".

12 Zie Catalog F T S 1995-6, 6v. Voor de ontwikkelingen aan theologische seminaries in de U S A, zie bijvoorbeeld het supplement Profile of Contemporary Seminarians Revisited van Theological Education 31 (1995). Het "Draft Two of Redeveloped Accrediting Standards" van January 1996 van de ATS formuleert kwaliteitseisen voor seminaries i z niveau van docenten, omvang van staf en studentental, studieduur, gerichtheid op kerk, academie en cultuur, internationalisering, bibliotheek, enzovoorts.

13 Uitvoerig hierover: R Mouw \& S Griffioen, Pluralism and Horizons, Grand Rapids 1993.

14 Een grond ligt in het Evangelie dat werkelijk verstaan moet worden en zelf een kritische grondtoon heeft. Een andere grond ligt in het belang van de kerk aan mensen die kritisch kunnen denken en creatief op nieuwe situaties kunnen reageren.

15 H M Kuitert, Filosofie van de theologie, Leiden 1988, 81.

$16 \quad$ Kuitert, op cit, 82.

$17 \quad$ Kuitert, op cit, 95.

18 H W de Knijff, “Theologie, wetenschap en universiteit", in: F G M Broeyer en T van Willigenburg (red), Facultas Theologica: Soror sororum (Utrechtse Theologische Reeks 27), Utrecht 1994, $101 \mathrm{v}$.

19 De Knijff, op cit, 100.

20 Ik probeerde in Religies en de waarheid, Kampen 1988 het éen en in Geen andere goden, Kampen 1993 het ander. 